\title{
En renæssancebygmester og hans bygningstyper i det sønderjyske område
}

\author{
Af Rigmor Lovring
}

Sønderjylland var den del af Danmark, hvor renæssancens arkitektur blev præsenteret og accepteret, før den for alvor slog igennem i den øvrige del af landets byggeri. For fremstødet i det sønderjyske område stod en bygmester ved navn Hercules von Oberberg, hvis indsigt og forståelse for tidens arkitekturopfattelse fik stor betydning for det sønderjyske herregårdsbyggeri i sidste halvdel af 1500 -tallet.

De begivenheder, som havde udspillet sig i riget, dannede forudsætning for det nybrud, som kom på arkitekturens område. Ved grevefejdens ophør i 1536 var adelens økonomiske magt svækket. Mange af dens borge var ødelagte eller nedbrændte. Landets økonomi, der samtidig var svag, gjorde, at ved genopbygning af borgene var det kun kongen, som kunne tillade sig et stærkt forsvar.

Kongens byggeri bestod først og fremmest $i$ at forstærke og befæste sine borge rundt $i$ landet, og der var for største delens vedkommende tale om en ombygning, hvor det middelalderlige bygningskompleks blev inddraget ved genopførelsen.

Anderledes forholdt det sig med adelens byggeri. Dens økonomi tillod ikke det store forsvar, og her blev der kun tale om voldgrave og en udkraget skyttegang. Dette forsvar kunne holde oprørske bønder på afstand; men i krig ville det ikke være meget bevendt. Derimod kom dens byggeri til at spille en væsentlig rolle $\mathrm{i}$ stiludviklingen inden for arkitekturen. Efterhånden som landet igen kom på fode, og den ikke længere behøvede at frygte noget angreb, begyndte adelens byggeri at blomstre. $\mathrm{Nu}$, hvor borgen blev lagt fri, sås nye former at vinde indpas. En gryende dansk renæssance begyndte at vise sig inden for arkitekturbyggeriet, og i den forbindelse er det, at Hercules von Oberberg bliver fremtradende som bygmester.

Det er ikke meget, man med sikkerhed ved om Hercules von Oberberg (ca. 1520/30-1602), før han i 1557 blev ansat som kongelig bygmester under Christian 4.

I sin ungdom havde han arbejdet for markgreve Johan af BrandenburgKüstrin på slottet i Küstrin, hvor han formodentlig har været ansat ved 
befæstningsarbejdet, da hans første arbejder i Danmark er af denne karakter. Han nævnes i forbindelse med bl.a. projektering ved Københavns befæstning, mindre istandsættelser på Koldinghus og Nyborg Slot samt Sønderborg Slot og det bastionære befæstningsanlæg på Krogen (Kronborg).

Hans arbejde som arkitekt må have været af betydning, hvilket beror på, at han få år efter sin ankomst ansattes som kongelig bygmester. I de to år, 1557-59, han arbejdede under Christian 3., var han beskæftiget rundt i riget ved de kongelige borge. Da Frederik 2. blev konge 1559, afskedigedes Hercules von Oberberg. Men dermed var hans karriere ikke slut. Tværtimod syntes han nu at få mulighed for at vise sine kundskaber inden for renæssancebyggeriet $\mathrm{i}$ det civile herregårdsbyggeri, og det blev nu i det sønderjyske område.

De grundtyper, han benyttede i sine bygningsværker, viste et klart brud med den middelalderlige tradition. Tidligere var bygningens regularitet gerne brudt ved forskellige fremspring på bygningen, og symmetrien manglede ofte

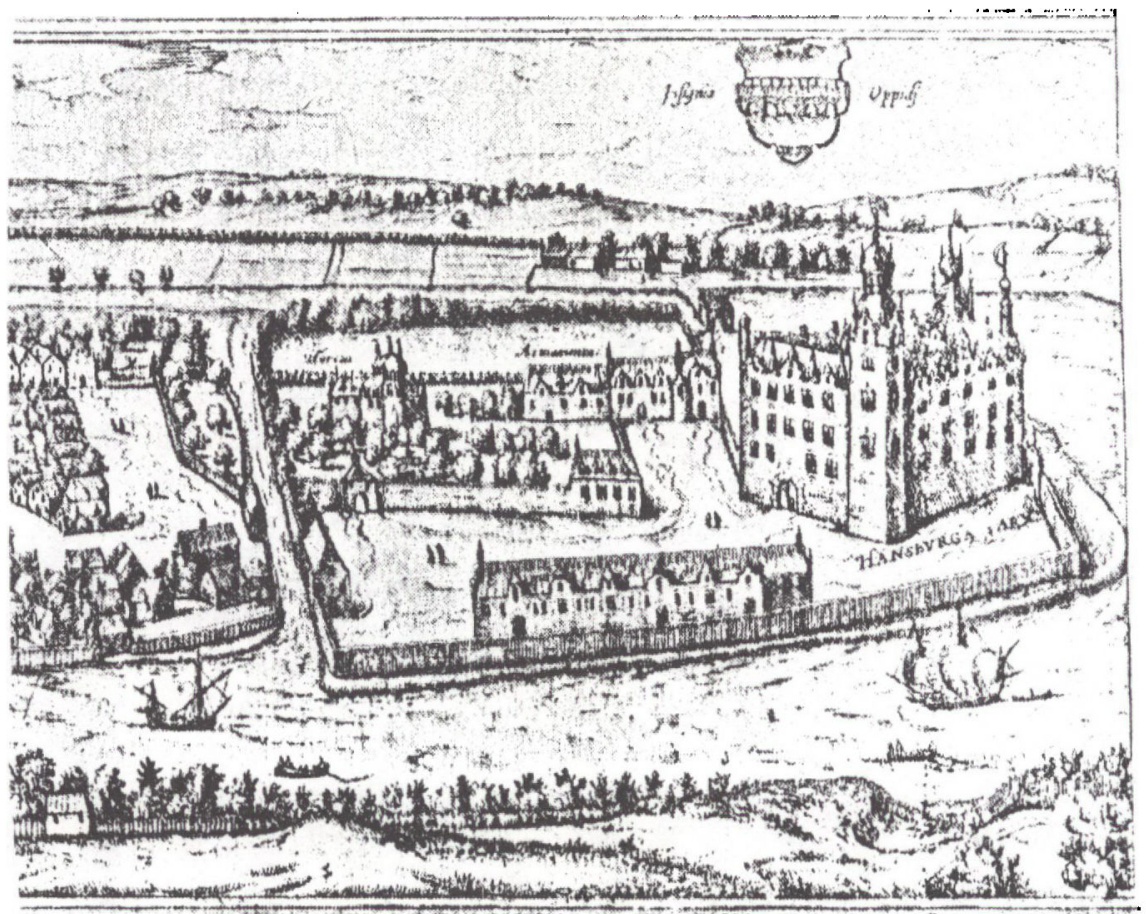

Fig. l. Hansborg. Det eneste eksisterende billede, der er fra ca. 1600, findes i Braunius' Theatrum Urbium. 


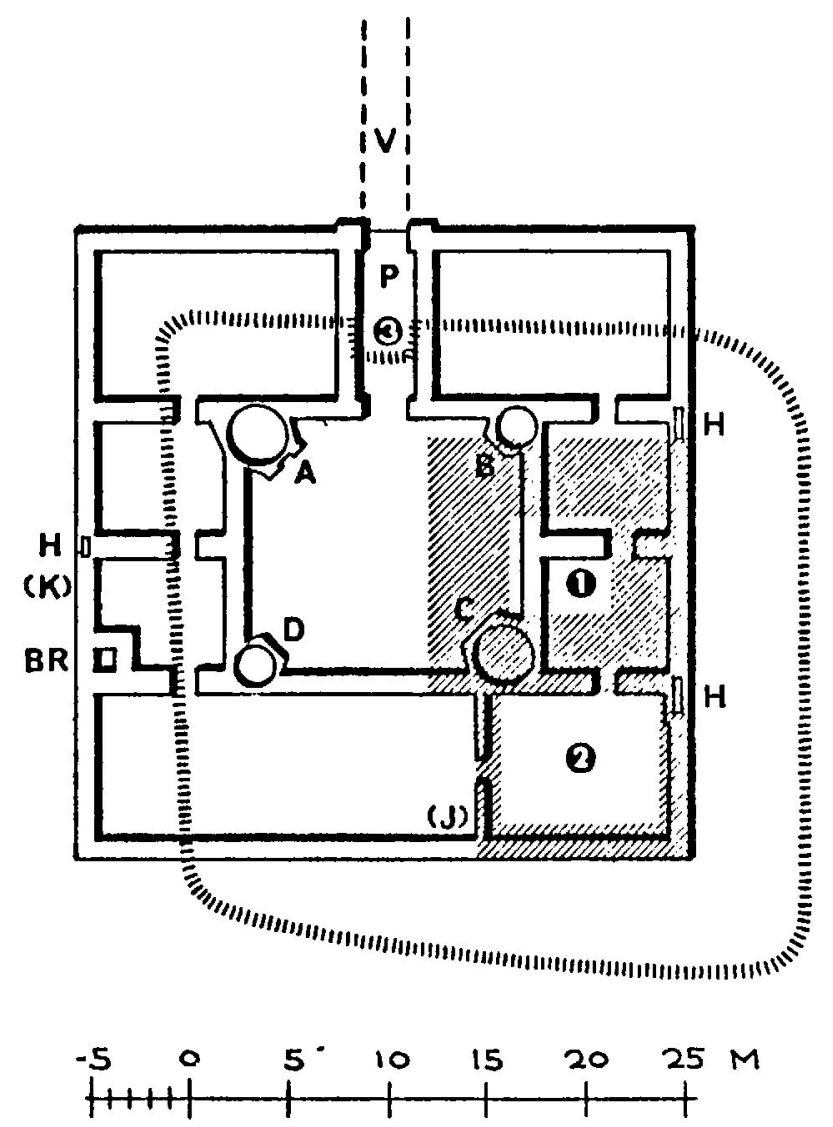

Fig. 2. Trejborgs grundplan. (Efter Trap Danmark).

helt. Oberberg havde klart forstået den symmetri, som prægede renæssancens byggeri, hvilket ses $i$ de tre grundtyper, han anvendte i sit byggeri.

Den første grundplan er det firfløjede bygningskompleks, hvor fløjene står vinkelrette på hinanden, og med to diagonaltårne. Et tydeligt eksempel herpå er Hansborg (fig. 1).

Den næste grundplan er ligeledes et firfløjet kompleks med fløjene vinkelrette på hinanden, men med en fremherskende aksefasthed. Trøjborg (fig. 2) opfylder disse krav fuldt ud.

Den tredje og sidste grundplan er den såkaldte "une maison tout une masse «. Dvs. et kvadratisk eller rektangulært centralhus, hvortil føjer sig fire tårne eller pavilloner. Af de bygningsværker af denne type, hvortil Oberbergs navn er tilknyttet, kan nævnes Tønning Slot (fig. 3). 
Fig. 3. Tonning Slot-prospekt og grundplan. (Efter Peter Hirschfeld: Herrenhäuser und Schlösser in Schleswig-Holstein).

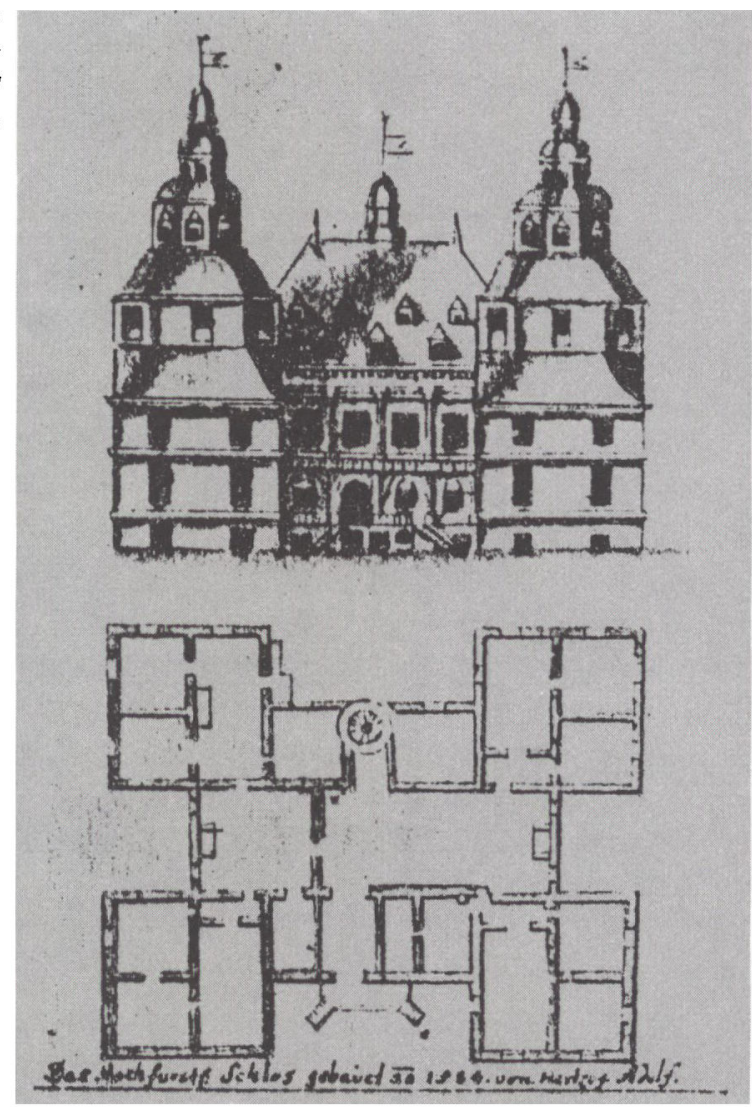

De første bygningsværker af civil karakter, Sønderborg Slot (fig. 4) og Hansborg, som Hercules von Oberberg kom til at beskæftige sig med, havde allerede en fastlagt grundplan. Sønderborg Slots gamle ringmur måtte ved ombygningen indgå i slotsanlægget. Derfor er grundplanens regularitet ikke helt gennemført. Men Oberberg har til fulde benyttet sin arkitektoniske viden, så bygningskomplekset kom til at fremtræde som et homogent hele. Bygningens skævhed modgås ved afmåling og opsætning af bygningens dekorative elementer. I slottets ombygning indgik også de gamle runde hjørnetårne.

Ved Hansborg var arbejdet lettere. Her havde den tidligere bygmester Rübensaat påbegyndt opførelsen af vestfløjen; men da arbejdet ikke var så vidt fremskredet, kom opførelsen af slottet til at påhvile Oberberg. Om han har fulgt grundplanen eller eventuelt udbygget den, vides ikke med sikkerhed. 


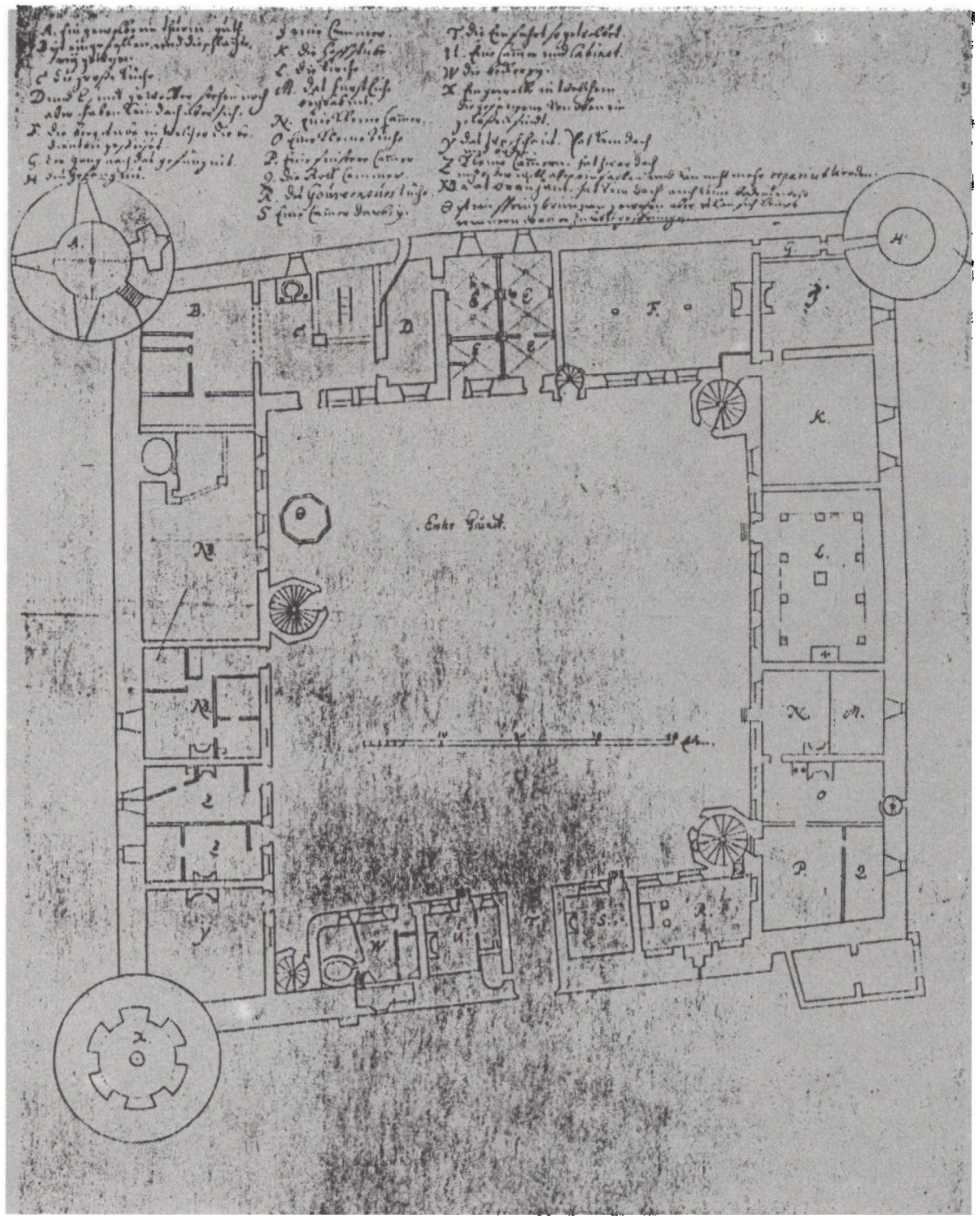

Fig. 4. Senderborg Slot - planen af stueetagen. (Efter Otto Norn: Christian III's borge).

Bygningen fremtrådte som en firfløjet regulær bygning. To diagonalt stillede hjørnetårne, næsten helt indbygget $\mathrm{i}$ bygningen, indgik $\mathrm{i}$ den afbalancerede grundplan. Bygningen var i tre stokværk, hvor diagonaltårnene var et stokværk højere end den øvrige bygning. I eksteriøret sås en klar symmetri. Her var vinduerne anbragt aksefast over hinanden, så det ene fag svarede til det andet. Kun de indre trappers vælske buer samt enkelte småspir brød 
bygningens symmetri. Renæssancens principper kom til udtryk i de regulære og klart definerede enkeltheder.

Trøjborg kan næsten betragtes som en kopi af et italiensk renæssancepalads. Her er tale om en kvadratisk grundplan med fløjene stillet vinkelret på hinanden. En del af østfløjen var opført på de middelalderlige fundamenter, medens bygningens øvrige dele var på nye fundamenter. Bygningen var et symmetrisk firfløjsanlæg bygget $\mathrm{i}$ to stokværk. I slotsgårdens hjørner var anbragt fire polygonale trappetårne med etagespir. Deres kupler rakte knap op over taget for ikke at bryde bygningens symmetri.

I bygningens ydre facade havde han gennemført renæssancens princip om regularitet. Nederst var en granitsokkel, som nåede til kældervinduernes underste kant. De følgende to stokværk var $\mathrm{i}$ tegl. Vinduerne var indsat $\mathrm{i}$ et fast aksesystem og hvert vindue med en trekantgavl. Etagerne var inddelte med sandstensgesims. Der var gennemløbende saddeltage med svungne gavle og gavlskorstene. Ved at betone begge hovedakserne $\mathrm{i}$ bygningen var der tilstræbt en fuldkommen symmetri.

I grundplanen "une maison tout une masse « er Oberberg fuldt fortrolig med en bygningstype, italieneren Sebastiano Serlio nøje har behandlet i sine arkitekturtraktater, og som i sidste halvdel af 1500-tallet vandt indpas mange steder i Europa. Hercules von Oberbergs navn sættes i forbindelse med tre bygninger af denne type: Tønning Slot, Grøngård og Østerholm. For de sidste to bygningers vedkommende er det grundplanen og dens udformning, der ligger til grund for tilskrivningen til Oberberg, da der intet skriftlige materiale findes, som sammenkæder hans navn med disse bygninger.

Ældst er Grøngård, der var hertug Hans den Ældres jagtslot. Tidsmæssigt må den vare fra 1567 , da breve udsendt af hertug Hans er udstedt på Grøngård dette år. Slottet var næsten kvadratisk og har været opført i røde teglsten med sandstensornamenter. Det har været forsynet med fire ottekantede hjørnetårne, hvoraf de to sydlige var anbragt lidt skævt på bygningen. Grundplanen (fig. 5) viser slottets regularitet, der sammen med de dekorative sandstensfragmenter, man har fundet, peger på en bygmester, der har forstået og været kendt med de nye arkitekturstrømninger.

Efter hertug Hans den Ældres død blev bl.a. Grøngård overdraget til hertug Adolf af Holsten-Gottorp, som i 1580 lod Oberberg bygge Tønning Slot. Der er her tale om et centralhus med hjørnetårne. Blot var tårnene denne gang blevet til mægtige pavilloner, der hver kronedes af dominerende tårne. Husets rektangulære grundplan blev fuldstændig domineret af de fire kvadratiske hjørnepavilloner. Centralhuset må tænkes som en slags gennemgangslokale og opholdsrum, der samtidig dannede forbindelse mellem de fire beboelsespavilloner. En indvendig vindeltrappe, som var indfældet $i$ central- 


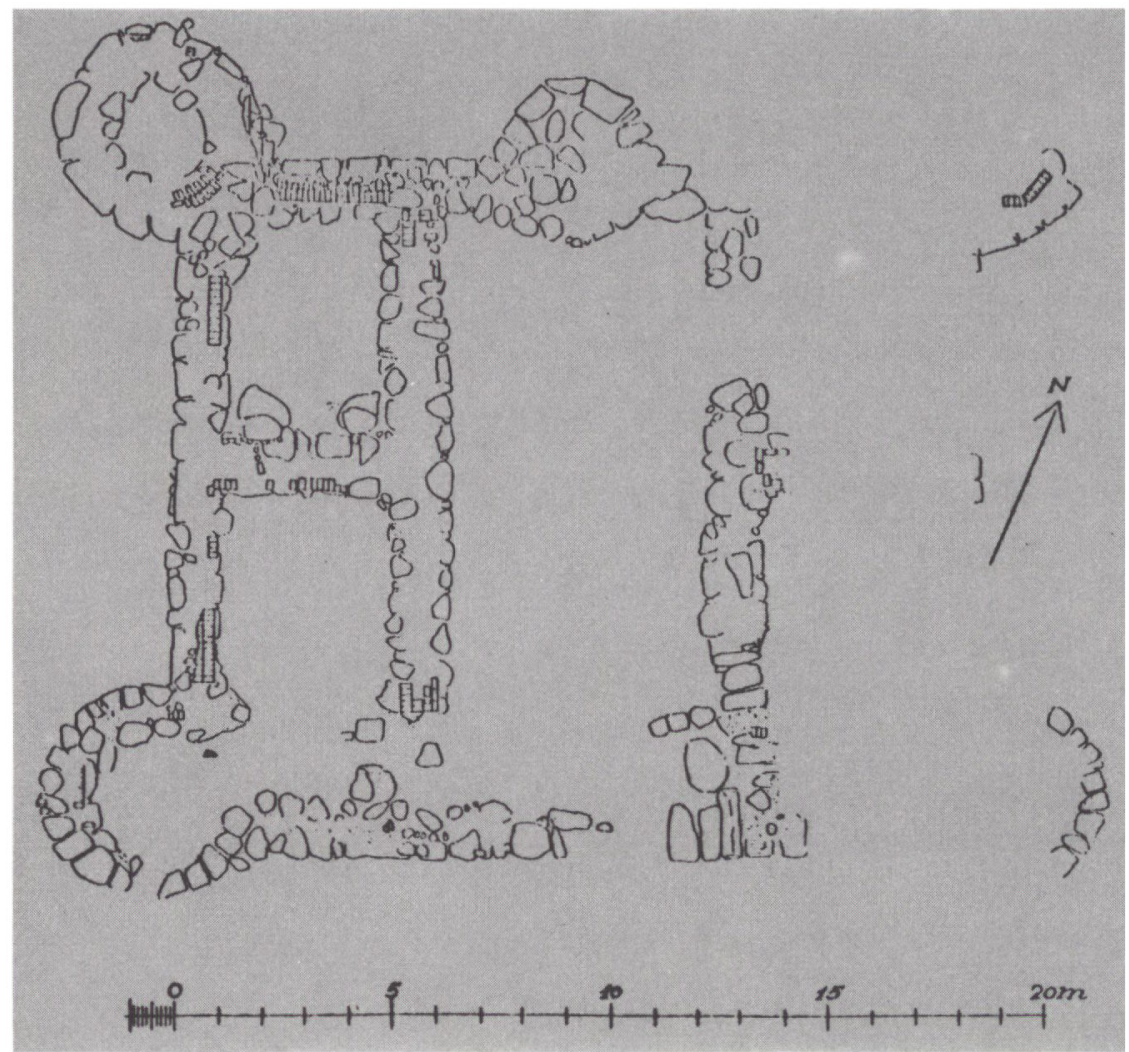

Fig. 5. Grengårds grundplan. (Efter Nationalmuseets Arbejdsmark 1956).

husets bagside, dannede forbindelse mellem de forskellige stokværk. Centralbygningen var opført $i$ to stokværk, medens hjørnepavillonerne var $i$ tre stokværk. Bygningens eksteriør viste vinduerne indsat i et fast aksesystem, hvor gesimsbånd adskilte de forskellige stokværk. Over andet stokværk kronedes bygningen af en balustrade, der løb omkring både centralbygningen og pavillonerne. Et stejlt saddeltag kronede centralbygningen, og over hjørnepavillonerne rejstes fire mægtige ottekantede tårne. Et mindre tårn var anbragt over den omtalte trappe, som forbandt de forskellige stokværk. Bygningens hovedparti havde en rig udsmykning med pilastre, medens hovedindgangen var anbragt lidt skævt på facaden.

Grundplanen viser en gennemtænkt regularitet, der får pavillonerne til at føje sig til bygningens kerne og danne en geometrisk helhed. Sammenlignet med Grøngårds grundplan, ses Tønning Slot at udvise en enhed, hvor 
centralhus og pavilloner går op $i$ et samlet hele, medens Grøngårds hjørnetårne virker som påsatte bygninger.

I 1590'erne ombyggede hertug Hans den Yngre Helvitgård og kaldte den nu for Østerholm. Den tidligere rektangulære bygning fik tilføjet to diagonalt stillede hjørnetårne. Bygningens grundplan giver en formodning om, at der kan være tale om et dobbelthus. Bygningen var opført i tre stokværk og havde, hvad arkæologiske udgravninger viser, været udsmykket i stil med de allerede omtalte bygninger, hvilket gør, at man tilskriver Hercules von Oberberg Østerholms bygninger. Blot sås trappehuset her at have en ligeløbende trappe, hvilket ikke var tilfældet $\mathrm{i}$ de øvrige behandlede bygningstyper.

Af de behandlede grundplaner ses Hercules von Oberberg at have haft kendskab til de klassiske principper og fulgt deres love angående symmetri og aksefasthed. I bygningens ydre fulgte han det op, dog stærkt påvirket af den nordeuropæiske renæssance, hvor det gjaldt udsmykningen.

Ser man på bygningernes indre struktur, har denne endnu hvilet på de middelalderlige principper. Her tænkes specielt på rummenes placering, hvor skillevægge, som gik fra ydermur til ydermur, gjorde, at man var nødt til at passere igennem de forskellige rum for at komme fra den ene ende af bygningen til denanden. I Østerholm havde der, som før omtalt, været indbygget en ligeløbende trappe efter nyt mønster; men ellers har det været den middelalderlige rundtrappe, som har været benyttet. Trappens placering er for firfløjsanlægget henlagt til gårdsiden, og $\mathrm{i}$ »une masse “ er den indbygget $i$ huset.

1 udsmykningen sås renæssancens påvirkning f.eks. i vinduernes aksefaste placering samt den rige sandstensudsmykning omkring disse. Gesimser delte de forskellige stokværk, og portalerne var gerne smykket med søjler.

Et nederlandsk præg havde de svungne gavle med sandstensindfatninger, smykket med volutter, kugler og obelisker, og mange gange gennembrudte af gesimser og pilastre. Også de små kvistgavle, der enten som rundbuer eller trekantgavle med kamstillede pinakler, samt trappetårnenes kuplede hætter, var med til at føre tanken hen på den nederlandske renæssancearkitektur.

Betegnende for Hercules von Oberberg var også hans kapelarkitektur. Her viste han sig som en af renæssancens mest modne mænd. I Haderslev indrettede han et af det danske riges første lutheransk-evangeliske fyrstekapeller. At han til fulde havde forstået og fuldbragt opgaven, må ses ved, at han indrettede både slotskapellet på Sønderborg Slot og som næsten 80-årig blev udpeget til at forestå kirkebyggeriet på Koldinghus.

Hercules von Oberbergs arkitek tur varslede den begyndende renæssance i dansk civilbyggeri, en ny arkitekturform, som man på dette tidspunkt endnu 
En renassancebygmester og hans bygningstyper $i$ det senderjyske område 53 ikke herhjemme var i stand til at honorere og forstå fuldt ud. Hans arbejder var hovedsageligt koncentreret i Sønderjylland, og det var først efter Oberbergs død, under Christian 4., at renæssancen for alvor satte sit præg på dansk civilarkitektur. Som foregangsmand inden for renæssancebyggeriet var Hercules von Oberbergs indsats betydelig. Men i tidens løb er næsten alle hans bygningsværker forsvundet, og i dag er kun Sønderborg Slot, omend i ombygget stand, og tårnet på Koldinghus slotsruin samt enkelte sparsomme bygningsfragmenter tilbage. 
